\title{
Third generation EGFR TKIs: current data and future directions
}

\author{
Chee-Seng Tan ', Nesaretnam Barr Kumarakulasinghe1, Yi-Qing Huang ', Yvonne Li En Ang ${ }^{1}$, Joan Rou-En Choo', \\ Boon-Cher Goh ${ }^{1,2,3}$ and Ross A. Soo 1,2,4*
}

\begin{abstract}
Acquired T790 M mutation is the commonest cause of resistance for advanced non-small cell lung cancer (NSCLC) epidermal growth factor receptor (EGFR) mutant patients who had progressed after first line EGFR TKI (tyrosine kinase inhibitor). Several third generation EGFR TKIs which are EGFR mutant selective and wild-type (WT) sparing were developed to treat these patients with T790 M acquired resistant mutation. Osimertinib is one of the third generation EGFR TKIs and is currently the most advanced in clinical development. Unfortunately, despite good initial response, patients who was treated with third generation EGFR TKI would develop acquired resistance and several mechanisms had been identified and the commonest being C797S mutation at exon 20. Several novel treatment options were being developed for patients who had progressed on third generation EGFR TKI but they are still in the early phase of development. Osimertinib under FLAURA study had been shown to have better progression-free survival over first generation EGFR TKI in the first line setting and likely will become the new standard of care.
\end{abstract}

Keywords: Third generation EGFR TKI, T790 M, Osimertinib, Resistance mechanism, FLAURA, Sequencing

\section{Background}

In 2009, the IPASS study established the superiority of gefitinib over chemotherapy for metastatic non-small cell lung cancer (NSCLC) patients with sensitizing epidermal growth factor receptor (EGFR) mutations [1]. Several first line phase III studies on first (gefitinib, erlotinib) and second (afatinib, dacomitinib) generation EGFR TKIs showed objective response rate and progression free survival (PFS) of patients with sensitizing EGFR to be $60-70 \%$ and 9 to 15 months, respectively [1-8].

Despite the initial high response rates, patients on EGFR TKIs will inevitably become resistant to treatment. Various mechanisms of acquired resistance have been identified and these can be divided into secondary mutations in EGFR, the activation of alternative signaling pathways, and phenotypic or histologic transformation [9-11]. The commonest mechanism of acquired

\footnotetext{
* Correspondence: ross_soo@nuhs.edu.sg

'Department of Haematology-Oncology, National University Cancer Institute of Singapore, National University Health System, 1E Kent Ridge Road, NUHS Tower Block, Level 7, Singapore 119228, Singapore

${ }^{2}$ Cancer Science Institute of Singapore, National University of Singapore, Singapore, Singapore

Full list of author information is available at the end of the article
}

resistance is T790 $\mathrm{M}$ mutation accounting for $50-60 \%$ of secondary resistance to primary EGFR TKI therapy [12]. This is also the basis for the development of third generation EGFR TKIs. The full discussion on the acquired mechanisms of resistance to first and second generation EGFR TKIs is beyond the scope of this article. Please refer to the following articles for a comprehensive review on this topic $[9,13]$.

\section{Third generation TKIs}

Given the limited efficacy of second generation TKIs in circumventing T790 M resistance to first generation TKIs, third generation TKIs were developed. These include osimertinib, EGF816, olmutinib, PF-06747775, YH5448, avitinib and rociletinib. The defining characteristic of these third generation agents is that they have significantly greater activity in EGFR mutant cells than in EGFR WT cells, making them mutant-selective [14]. The only approved third generation TKI is osimertinib. In the rest of this article, we will review the preclinical and clinical data surrounding osimertinib and other third generation EGFR TKIs, as well as future challenges 
on the evaluation and treatment of resistance that arises from these third generation EGFR TKIs.

\section{Osimertinib: pre-clinical and clinical data}

Osimertinib, an oral third-generation EGFR TKI selectively and irreversibly targets both sensitizing EGFR mutations as well as T790 $\mathrm{M}$ while sparing the wild-type EGFR tyrosine kinase [15]. Osimertinib, a mono-anilinopyrimidine compound is less potent at inhibiting phosphorylation of EGFR in wild-type cell lines with close to 200 times greater potency against L858R/T790 M than wild-type EGFR [15]. In preclinical studies, osimertinib demonstrated impressive activity in xenograft and transgenic murine tumor models with both profound and sustained tumor regression [15]. In addition, osimertinib also induced sustained tumor regression in an EGFRmutated mouse brain metastases model [16].

The Phase I/II AURA trial was conducted to determine the safety and efficacy of osimertinib in patients ( $n$ = 252) who progressed on initial EGFR TKIs [17]. Diarrhea was the most frequent toxicity (47\%), followed by rash (40\%), nausea and decreased appetite (21\%). Despite G3 or higher toxicities noted in 32\% of patients, only 7\% and $6 \%$ of patients required a dose reduction or drug discontinuation. Of interest, 6 cases of potential pneumonitis-like events were reported. All 6 patients discontinued osimertinib. With regards to efficacy, the ORR was $51 \%$ and an impressive disease control rate (DCR) of $84 \%$. And the median PFS was 8.2 months. As expected, the subgroup of T790 M-positive patients ( $N$ $=127$ ) had an excellent DCR of $95 \%$, ORR of $61 \%$ and median PFS of 9.6 months. Activity was lower in patients ( $n=61)$ without EGFR T790 M mutations with an ORR and PFS of $21 \%$ and 2.8 months (95\% confidence interval (CI) 2.1-4.3) respectively.

Following the encouraging efficacy and safety date from the initial AURA Phase I/II study, the single arm, multi-center phase II Aura 2 study was conducted with osimertinib at $80 \mathrm{mg}$ orally daily [18]. All patients $(n=$ 210) had advanced NSCLC harboring EGFR T790 M mutations that was centrally confirmed and had progressed on prior EGFR TKI therapy. The ORR was 70\% with $3 \%$ complete responses and a DCR of $92 \%$. The median PFS was 9.9 months (95\% CI 8.5-12.3) with a median duration of response of 11.4 months. Overall, toxicities were manageable with the most common possibly treatment-related grade 3 or 4 AEs were prolonged electrocardiogram QT (2\%), neutropenia (1\%) and thrombocytopenia (1\%).

In a pooled analysis of the AURA extension and AURA2 Phase II studies $(n=50)$, the central nervous system (CNS) ORR with osimertinib dose at $80 \mathrm{mg}$ per day was $54 \%$ with $6(12 \%)$ complete responders. $82 \%$ of patients responded intracranially by 6-week assessment [19].
AURA3 was an open-label, international, phase III trial of 419 patients with locally advanced or metastatic NSCLC with T790 M mutations randomized 2:1 to osimertinib at $80 \mathrm{mg}$ daily $(n=279)$ or to standard-care pemetrexed plus platinum every 3 weeks, with maintenance pemetrexed allowed [20]. The median PFS was 10.1 months vs 4.4 months (hazard ratio (HR) 0.30 , 95\% CI $0.23-0.41, p<0.001)$. A higher ORR was seen in the osimertinib arm when compared to standard of care: (71\% vs $31 \%$, odds ratio: $5.39,95 \%$ CI $3.47-8.48, \mathrm{p}<$ 0.001 ). The responses were also durable at 9.7 months in the osimertinib group compared with 4.1 months for chemotherapy. Furthermore, all the patient reported outcomes (PROs) were better in the osimertinib group than in the platinum-pemetrexed group.

In patients with CNS metastases, the median PFS was 8.5 months versus 4.2 months (HR 0.32, 95\% CI 0.21$0.49)$. Only $5 \%(n=13)$ vs $14 \%(n=20)$ developed new CNS lesions while on treatment with osimertinib vs platinum/pemetrexed respectively. Among the patients receiving osimertinib, there was no significant difference in benefit between patients with T790 M-positive status on both tumor and plasma analyses and those in the intention-to-treat population.

Fewer patients reported adverse events of grade 3 or more in the osimertinib group (23\%) than in the platinum-pemetrexed group (64\%). In the osimertinib group, the most commonly reported adverse events were diarrhea (41\%), rash (34\%), dry skin (23\%), and paronychia (22\%). Interstitial lung disease-like adverse events were reported in 10 patients (4\%) in the osimertinib group. Nine patients had grade $\leq 2$ in severity and one death was reported. A prolongation in the QT interval was recorded in 10 patients (4\%) in the osimertinib group and 1 patient (1\%) in the platinum-pemetrexed group, with all events of grade 1 or 2 in severity except for one grade 3 event in the osimertinib group. Osimertinib was associated with a lower rate of permanent discontinuation, (7\% compared with $10 \%$ with chemotherapy). Fatal adverse events were reported in 4 patients in the osimertinib group and one treatment related death in the platinum-pemetrexed group. Refer Table 1 for summarized clinical efficacy for osimertinib.

In November 2015, osimertinib received accelerated approval under the Breakthrough Therapy Designation Program for metastatic epidermal growth factor receptor (EGFR) T790 M mutation-positive non-small cell lung cancer (NSCLC), as detected by an US FDA-approved test, whose disease has progressed on or after EGFR tyrosine kinase inhibitor (TKI) therapy. This was followed by recommendation by The European Medicines Agency (EMA) for conditional marketing authorization for Tagrisso (osimertinib) for same indication in December 2015 with marketing authorization 
Table 1 Selected clinical efficacy on selected third generation EGFR TKIs in clinical development

\begin{tabular}{|c|c|c|c|c|c|c|c|}
\hline Third Generation EGFR TKI & Status of development & Trial & Dose & $n$ & ORR & $\begin{array}{l}\text { PFS (mth) } \\
(95 \% \mathrm{Cl})\end{array}$ & $\begin{array}{l}\text { Adverse events } \\
\text { (selected all grade) }\end{array}$ \\
\hline $\begin{array}{l}\text { Osimertinib } \\
\text { (AZD9291) }\end{array}$ & $\begin{array}{l}\text { Approved for T790 } \\
\text { M mutation post } \\
\text { EGFR TKI }\end{array}$ & $\begin{array}{l}\text { AURA } 3 \\
\text { NCT01802632 }\end{array}$ & 80 mg daily & 279 & $\begin{array}{l}71 \% \\
(65-76 \%)\end{array}$ & $\begin{array}{l}10.1 \\
(8.3-12.3)\end{array}$ & $\begin{array}{l}\text { Diarrhea }(41 \%) \text {; rash }(34 \%), \\
\text { paronychia (22\%); pneumonitis } \\
(4 \%)\end{array}$ \\
\hline Olmutinib & Developing in Korea & NCT01588145 & 800 mg daily & 76 & $56 \%$ & $\begin{array}{l}7.0 \\
(5.5-8.3)\end{array}$ & $\begin{array}{l}\text { Diarrhea }(55 \%) \text {, rash }(39 \%) \text {, } \\
\text { nauseas (38\%). }\end{array}$ \\
\hline Nazartinib (EGF816) & Phase $1 / \|$ & NCT02108964 & 75-350 mg QD & 132 & $44 \%$ & $\begin{array}{l}9.2 \\
(9.0-\mathrm{NE})\end{array}$ & $\begin{array}{l}\text { Diarrhea (40\%), maculopapular } \\
\text { rash }(39 \%) \text {, pruritus (32\%), } \\
\text { stomatitis (23\%), and fatigue } \\
(21 \%) \text {. }\end{array}$ \\
\hline Avitinib (AC0010) & $\begin{array}{l}\text { Phase I/II } \\
\text { (phase II AEGIS-1 trial } \\
\text { had started) }\end{array}$ & NCT02330367 & $\begin{array}{l}50-350 \mathrm{mg} \text { BID } \\
150-300 \mathrm{mg} \text { cohort }\end{array}$ & $\begin{array}{l}136 \\
95\end{array}$ & $\begin{array}{l}44 \%^{a} \\
51 \%\end{array}$ & NA & Diarrhea (38\%) and rash (24\%) \\
\hline
\end{tabular}

EGFR epidermal growth factor receptor, TKI tyrosine kinase inhibitor, ORR objective response rate, PFS progression free survival, $n$ number of participant, NE not evaluable, NA not available

${ }^{a}$ including unconfirmed responses

approved in February 2016. Subsequently, Osimertinib received US FDA approval on March 30, 2017 based the confirmatory AURA3 study [20].

Osimertinib was evaluated in the front line setting compared to 1st generation EGFR TKIs in the FLAURA study. FLAURA was a Phase III, double-blind, randomized study assessing efficacy and safety of osimertinib versus standard of care EGFR-TKI (gefitinib or erlotinib) in the first-line treatment of patients $(n=556)$ with Ex19del/L858R EGFR mutated advanced NSCLC [21].

The primary endpoint PFS was 18.9 Months vs 10.2 months (HR 0.46, 0.37-0.57; $p<0.0001$ ) and the PFS benefit was consistent across all subgroups. Of special interest, the PFS of patients with known brain metastasis at study entry treated with osimertinib (HR 0.47) was similar to patients without known brain metastasis (HR 0.46). CNS progression was also significantly lower in patients treated with osimertinib $6 \%$ vs $15 \%$.

The ORR was similar for osimertinib and standard of care EGFR TKI at $80 \%$ and $76 \%$, respectively. The median duration of response was significantly longer in patients treated with osimertinib (17.2 vs 8.5 months). The overall survival (OS) data was only $25 \%$ mature at time of analysis and was not statistically significant however did show a positive trend (HR 0.63, 0.45-0.88; $p=$ $0.0068)$. A $p$-value of 0.0015 was required for statistical significance at the current OS maturity. Final OS analysis will be completed at approximately $60 \%$ maturity.

Compared to first generation EGFR TKI, osimertinib resulted in similar incidence of diarrhea ( $58 \%$ vs $57 \%$ ), higher risk of stomatitis (29\% vs $20 \%$ ), lower incidence of dermatitis acneiform ( $25 \%$ vs $48 \%$ ), elevated AST ( $9 \%$ VS 25\%) and elevated ALT (8\% VS 27\%). Grade $\geq 3$ adverse events occurred in $34 \%$ of osimertinib patients vs $45 \%$ in standard of care (SoC). Discontinuation of treatment due to adverse events occurred in 13\% of osimertinib patients vs $18 \%$ receiving SoC.
Based on the results from the FLAURA study, osimertinib can be consider a standard of care for patients with metastatic NSCLC with EGFR sensitizing mutations especially in patients with brain metastasis.

\section{Other third generation EGFR TKI under development}

Refer to Table 1 for summarized clinical efficacy of selected third generation EGFR TKIs that are in clinical development. Figure 1 summarized the pre -clinical efficacy based on IC50 nanoMolar (nM) comparing between first, second and selected third generation EGFR TKIs.

\section{Olmutinib (BI 1482694/HM61713)}

Olmutinib was investigated in phase I/II trial evaluating Korean NSCLC patients who had failed prior EGFR TKI. The recommended phase II dose was $800 \mathrm{mg}$ daily. In the phase II study of patients who were T790 M and the ORR was $56 \%$ achieved ORR with DCR of $90 \%$. The median PFS was 7.0 months (95\% CI 5.5-8.3). The commonest all grade adverse events were diarrhea (55\%), rash (39\%), nauseas (38\%) [22].

Boehringer Ingelheim collaborated with Hanmi Pharmaceutical to develop olmutinib in ELUXA trials. But the collaboration was halted in view of a South Korean Authority drug safety report of a fatal case of toxic epidermal necrolysis (TEN) [23, 24]. Olmutinib is currently being developed by Hanmi Pharmaceutical in South Korea.

\section{Nazartinib (EGF816)}

Pre-clinical data showed that nazartinib showed similar mutant-selectivity and EGFR wild-type sparing property similar to other third generation EGFR TKIs [25].

In a phase I dose-escalation study of nazartinib $(n=$ 132) over seven dose cohorts (75-350 mg QD), the confirmed ORR in 127 evaluable patients was 44\% (56/127) with a disease control rate of $91 \%$. The median PFS was 


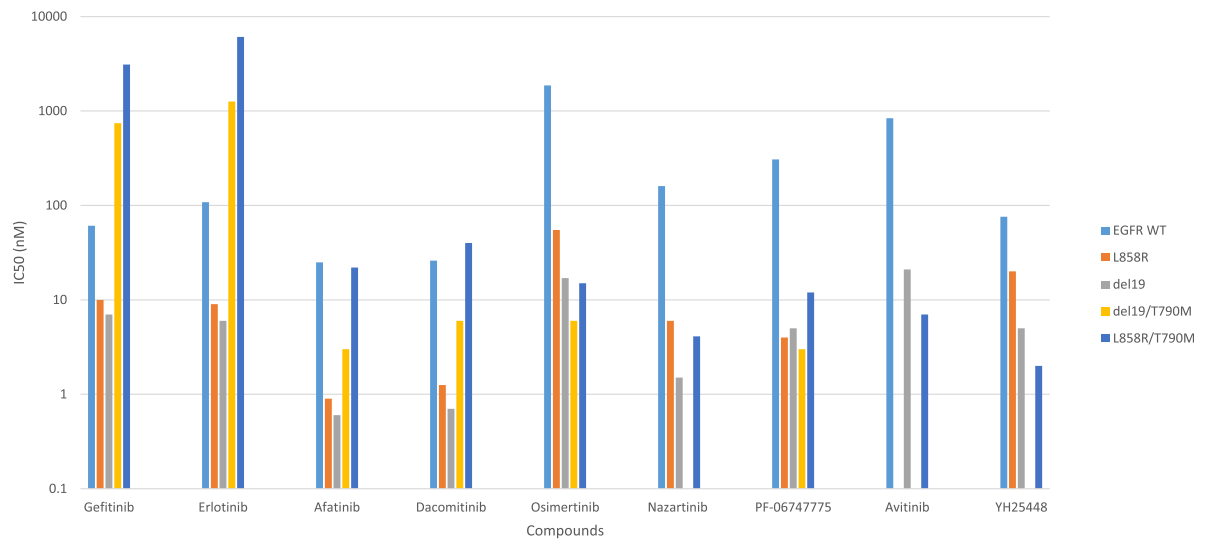

Fig. 1 Pre -clinical efficacy based on IC50 (nM) comparing between first, second and selected third generation EGFR TKIs. EGFR WT=epidermal growth factor wild-type. EGFR WT is based on H2O73 cell line for gefitinib, erlotinib, afatinib, dacomitinib, osimertinib; HaCaT cell line for nazartinib; A549 cell line for PF-06747775, A431 cell line for avitinib. L858R is based on H3255 cell line for all compounds. del19 is based on PC9 cell line for all compounds except HCC 827 cell line for nazartinib. del19/T790 M is based on PC9VanR cell line for all compounds. L858R/T790 M is based on H1975 cell line for all compounds

9.2 months (95\% CI 9.0-NE) [26]. All grade adverse events included diarrhea (40\%), maculopapular rash (39\%), pruritus (32\%), dry skin (23\%), stomatitis $(23 \%)$, and fatigue (21\%). Grade 3 or 4 adverse events included maculopapular rash (14\%), anemia (6\%), and diarrhea (6\%). Hepatitis B reactivation was reported in two patients who were not on antiviral prophylaxis. One patient resumed nazartinib after starting anti-viral and another patient died [26]. Nazartinib is also concurrently being investigated in combination with capmatinib (INC28), a cMET inhibitor, in a phase I/II study (NCT02335944).

\section{PF-06747775}

PF-06459988 is an irreversible pyrrolopyrimidine inhibitor of EGFR T790 M mutants. It has potent pre-clinical EGFR activity against the four common mutants (exon 19 deletion (Del), L858R, and double mutants T790 M/L858R and T790 M/Del), selectivity over wild-type EGFR [27].

In a phase I study where 44 EGFR mutant patients who had progressed on first line EGFR TKI were enrolled into six dose escalation $(25 \mathrm{mg}-600 \mathrm{mg}$ ) and 2 dose expansion cohorts $(200 \mathrm{mg}$ and $300 \mathrm{mg}$ ), the recommended phase 2 dose was $200 \mathrm{mg}$ daily. All grade adverse events of $>25 \%$ included diarrhea (57\%), rash (59\%), paronychia (52\%), dermatitis acneiform (34\%), stomatitis (32\%), pruritus (27\%), dry skin (25\%), and rhinorrhea (25\%). Commonest grade 3 diarrhea and skin toxicity which were and easily managed. No grade 4 treatment related AEs were reported. Efficacy data is ongoing [28].

\section{Avitinib (AC0010)}

Avitinib is a pyrrolopyrimidine-based irreversible EGFR inhibitor and is structurally distinct from other pyrimidine-based irreversible EGFR inhibitors such as osimertinib and has activity against EGFR mutations including T790 M whilst spares EGFR WT [29].

Avitinib was investigated in a phase I/II study for EGFR mutant patients who had progressed on first line EGFR TKI [30]. A total of 136 patients were treated across seven dose cohorts (50-350 mg BID). Responses were observed in all dose cohorts except $50 \mathrm{mg}$ BID. The ORR (including unconfirmed responses) and disease control rate (DCR) were $44 \%$ and $84 \%$ respectively. In the dose cohorts of 150-300 mg BID had ORR and DCR of $51 \%$ and $89 \%$ respectively. The recommended phase 2 dose (RP2D) was $300 \mathrm{mg}$ BID. Avitinib was well tolerated with diarrhea (38\%) and rash (24\%) which was predominantly of grade 1 or 2 severity. Grade 3 or 4 side effects included diarrhea (2\%) rash (2\%) transaminitis (2-4\%) [30]. In a subset of patients with brain metastases, the intracranial PFS of two patients were shorter than extracranial PFS. This finding may be attributed to a low blood-brain-barrier penetration rate of $0.046 \%-$ $0.146 \%[31]$.

\section{YH25448}

Early in vivo and in vitro data reported YH25448 had more potent inhibition of cancer cell growth compared to osimertinib in cancer cells harboring EGFR mutations (L858R/T790 M) with IC50 of $2 \mathrm{nM}$ vs $8 \mathrm{nM}$ and GI50 of $3.6 \mathrm{nM}$ vs $11.8 \mathrm{nM}$ respectively. YH25448 treatment in mice implanted with H1975 cells showed regression of tumor in both subcutaneous and intracranial lesions. At $10-25 \mathrm{mg} / \mathrm{kg}$, YH25448 achieved more significant, complete tumor growth inhibition and longer overall survival compared to same doses of osimertinib [32]. 
Ongoing effort is underway to develop this compound further.

\section{Rociletinib (CO-1686)}

Rociletinib was initially investigated in phase I/II study in TIGER-X trial for patients who had failed EGFR TKI in the first line setting. The ORR in patients harboring T790 M was 59\% and the DCR was $93 \%$. An updated pooled TIGER-X/TIGER-2 analysis reported a lower response rate of $34 \%$ for $625 \mathrm{mg}$ b.i.d. dose cohort $(n=$ $170)$ and $28 \%$ for $500 \mathrm{mg}$ b.i.d. dose cohort $(n=79)$ [33]. In the latest analysis of TIGER-X reported in June 2016, the confirmed ORR was $45 \%$ (95\% CI, 31 to 60 ) and 18 patients with T790 M-negative disease, the confirmed ORR was $17 \%$ (95\% CI, 4 to 41) [34]. Based on this updated data showing lower than expected efficacy, FDA voted against the accelerated approval of rociletinib and Clovis subsequently stopped the clinical development.

\section{ASP8273}

In a phase I/II trial of ASP8273 in Japanese patients with EGFR mutant NSCLC who had progressed on first line EGFR TKI, the ORR was 50\%for all patients dosed with $\geq 100 \mathrm{mg}$ with ORR of and $80 \%$ in T790 M positive patients. The most common all grade adverse events were diarrhea (56\%), nausea (31\%), vomiting (31\%) and thrombocytopenia (31\%). Less commonly, skin rash (9\%) and interstitial lung disease (ILD)-like events (2\%). Maximum tolerated dose (MTD) was determined at $400 \mathrm{mg}$ and the R2PD dose was $300 \mathrm{mg}$ [35].

In a North American study $(n=60)$, of patients with EGFR mutated NSCLC who have progressed after EGFR TKI90\% of patients had T790 M mutation. In the T790 M positive cohort, the ORR was 37.5\% (15/40) and DCR was $65 \%(26 / 40)$. The median PFS was 6.7 months (95\% CI: 5.32-9.79 months) [36]. AA phase III study evaluating ASP8273 versus first generation EGFR TKI in the first line treatment of EGFR mutant advanced NSCLC (SOLAR) was subsequently initiated. However, on the recommendation of the Independent Data Monitoring Committee, the trial was discontinued in May 2017 due to lack of clinical efficacy [37].

\section{Challenges in treatment of advanced EGFR mutant patients}

a) Detection of EGFR T790 M mutations with plasma sample

At disease progression, a biopsy of tumor tissue is typically performed to evaluate for targetable resistance mechanisms such as EGFR T790 M mutation. However, procedures are invasive and not always feasible in patients with advanced disease, with up to $28 \%$ of NSCLC patients unable to provide a biopsy sample suitable for mutational analysis [38]. "Liquid biopsy" has been developed to counter conventional tissue biopsy limitations. Benefits over tissue biopsy include the ability to capture tumor heterogeneity and to quantify the number of mutated gene copies which is useful for monitoring disease response and predicting early treatment failure [39, 40]. Importantly, it is noninvasive, where repeated testing can be done for dynamic monitoring of tumor molecular changes [41].

\section{Circulating tumor cells (CTCs)}

Once isolated, CTCs can be used to analyze EGFR mutational status [42]. Additionally, immunohistochemistry or fluorescence in-situ hybridization which cannot be done on fragmented plasma ctDNA samples, can be performed on CTCs to evaluate for other rearrangements, mutations or amplifications [43].

\section{Plasma cell-free circulating tumor DNA (ctDNA) for the detection of T790 M}

Several platforms have been used to detect ctDNA and these included the amplified refractory mutation system (ARMS), peptide nucleic acid mediated polymerase chain reaction (PCR) clamping, digital PCR, denaturing high performance liquid chromatography (DHPLC) and next generation sequencing (NGS). A comprehensive review of "liquid biopsy" is beyond the scope of this review article. Please refer to these review articles for more information $[44,45]$.

Of the methods available, ARMS, AdPCR and BEAMing have been determined to be clinically applicable in the setting of resistance to EGFR TKIs and the development of the T790 M mutation. Studies have demonstrated high sensitivity, specificity and good concordance between these strategies and actual tissue biopsy results. Thress and colleagues evaluated plasma samples from patients recruited to the AURA 1 trial prior to initiation of osimertinib. The sensitivity and specificity were $73 \%$ and $67 \%$ respectively with cobas ${ }^{\circ}$, and $81 \%$ and $58 \%$ respectively with BEAMing in detection of T790 M. Concordance between the platforms was >90\% [46]. Karlovich et al. also demonstrated a high concordance rate between matched plasma and tumor tissue samples drawn from the phase I clinical trial of rociletinib, where the concordance rate for T790 M was $64 \%$ with cobas ${ }^{\circ}$ and $73 \%$ with BEAMing [47]. Table 2 summarizes the sensitivity and specificity for T790 M mutation testing based on various plasma assay platforms.

b) Mechanisms of resistance to 3rd generation TKI

Despite initial impressive outcomes with 3rd generation EGFR TKIs, acquired resistance invariably 


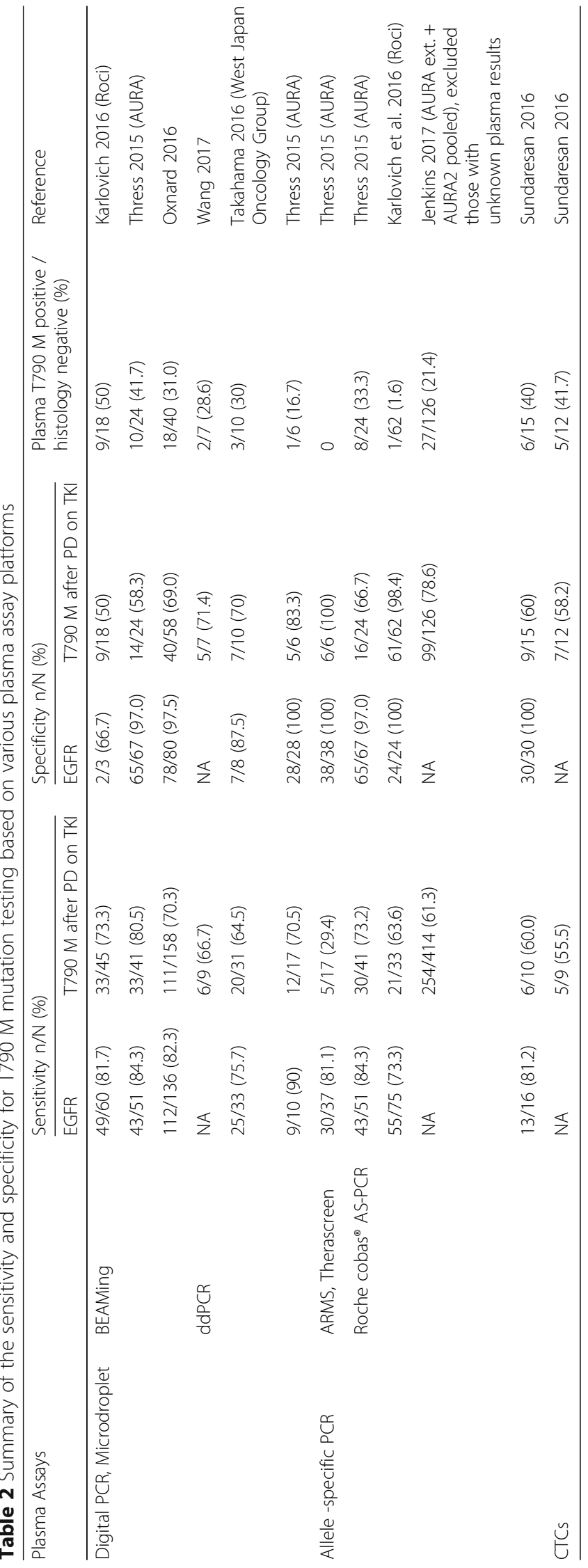


develops. Several mechanisms of resistance that are EGFR-dependent and EGFR-independent have been described. EGFR-dependent mechanisms include the development of EGFR C797S mutation whereas examples of EGFR-independent mechanisms include activation of pathways downstream of EGFR and parallel signaling pathways (Table 3).

\section{EGFR C797 mutation}

One of the first mutations reported was the C797S mutation, a point mutation on exon 20. This mutation abolishes the covalent bonding of osimertinib to EGFR [48]. Its prevalence ranges between $22 \%$ to $40 \%$ - being identified in 22 out of 99 NSCLC patients who have progressed on osimertinib [49], and 6 out of 15 patients in the phase I AURA study [50] respectively.

In addition to osimertinib, C797S mutation has also been reported to mediate resistance to other thirdgeneration TKIs, such as HM61713 olmutinib [51], rociletinib [52] and nazartinib [53]. Chabon and colleagues analyzed pre- and post- treatment samples from 43 patients treated with rociletinib. Only 1 out of 43 (2\%) developed C797S mutation in cis with T790 M, a frequency that is lower compared to that of Osimertinib. Piotrowska also found no C797S mutation in a group of 12 patients who progressed on rociletinib [54]. These evidences suggest a potential difference in the pattern of resistance between osimertinib and rociletinib. Recently, Tan et al. reported genomic profile of 9 resistant tumor samples, following progression on EGF816 nazartinib. C797S mutation was identified in one patient, who also had concurrent MTOR deletion [53].

Preclinical studies have demonstrated the acquired C797S mutation in cells resistant to 3rd generation TKIs $[48,55]$. Of interest was the finding that the allelic context in which $\mathrm{C} 797 \mathrm{~S}$ was acquired may predict responsiveness to subsequent TKI treatments [55].

A recent study by Piotrowska and colleagues evaluated Guardant Health database of plasma samples of 61 lung adenocarcinoma patients with C797S mutation. These patients had acquired T790 M mutation and were treated with osimertinib. The study found the following C797S configuration: C797S/T790 $\mathrm{M}$ in cis in 50 patients (82\%); C797S/T790 M in trans in 6 patients (10\%); C797S alone without T790 M in 4 patients (6\%); and 1 patient (2\%) had two co-existent C797S clones (one in cis with T790 $\mathrm{M}$ and one in trans) [56]. In addition, 51 patients $(84 \%)$ had at least one bona fide resistance mechanism co-occurring with C797S, namely EGFR amplification $(n=29 ; 48 \%) ; M E T$ amplification $(n=10$; $16 \%) ; B R A F$ V600E $(n=3 ; 5 \%)$ and PIK3CA mutation $(n$ $=9 ; 15 \%)$. Interestingly, C797S can sometimes be polyclonal within individual patients. Thus, the polyclonality of C797S, together with co-existing resistance mechanisms, highlight the heterogeneity of resistant EGFR-mutant cancers.

Other than C797S, a case report by Menon et al. demonstrated a novel $\mathrm{C} 797$ variant in a patient who has progressed on osimertinib. The authors found a C797G mutation in cis with T790 M. Focal MYC and EGFR amplifications were also isolated in the same patient [57].

\section{Other EGFR mutations}

In addition to the C797S mutation, other EGFR mutations such as L792 and L718 mutations have also been reported [58-61]. Interestingly, all L792 mutations are in cis with $\mathrm{T} 790 \mathrm{M}$ and in trans with $\mathrm{C} 797$ mutations when present in the same patient. In addition, 2 out of 10 L792-positive patients and 6 out of 7 L718-positive patients did not have co-existing C797 mutations. This suggests that C797-, L792- and L718- mutated cells are likely different resistant clones [58].

Other EGFR L798I, E709K, L792 V and G796S/R mutations had also been described [52, 59, 62, 63].

\section{Bypass mechanisms}

Other resistance mechanisms to osimertinib identified involve either activation of pathways downstream of EGFR (RAS-MAPK pathway signaling) or those that activate parallel signaling pathways, such as Her2 amplification, MET amplification, PTEN loss and PIK3CA mutation.

\section{RAS-MAPK}

KRAS mutation, KRAS amplification, BRAF, NRAS (including a novel NRAS E6K mutation) and MEK1 mutation have been described as mechanisms of acquired resistance to third generation TKIs [49, 52, 64-66]. KRAS G12S, G12A, Q61H, A146T and G12D mutation had been reported post third generation EGFR TKI [52, $64,65]$.

Other than KRAS mutations, NRAS mutations have also been reported preclinically. NRAS missense mutations (including a novel E63K mutation) or NRAS copy number gain had been reported post osimertinib. Interestingly, these resistant cell lines were sensitive to combination therapy of $M E K$ inhibitor selumetinib with EGFR TKI [66].

Lastly, a BRAF V600E mutation was uncovered as resistant mechanism to osimertinib in two reports [49, 67]. Notably, in one study, combination of BRAF inhibitor encorafenib together with osimertinib was attempted and led to significant inhibitory effects on cell lines [67].

\section{Her2 and MET amplification}

Amplification of Her2 and MET have been described after progression on third generation TKIs [49, 52, 53, 
Table 3 Mechanisms of resistance to third generation EGFR TKIs

\begin{tabular}{|c|c|c|c|c|c|}
\hline Mechanism & Author & 3rd gen EGFR TKI & Sample & Method & Other mechanisms (no. of patients) \\
\hline \multicolumn{6}{|c|}{ EGFR-dependent mechanisms of resistance to third generation TKIs } \\
\hline \multirow[t]{4}{*}{ C797S } & $\begin{array}{l}\text { Thress et al. } \\
\text { Yu et al. } \\
\text { Ortiz Cuaran } \\
\text { Ramalingam } \\
\text { Ig Ou } \\
\text { Ou ASCO } \\
\text { Piotrowska WCLC }\end{array}$ & Osimertinib & $\begin{array}{l}\text { Plasma/Tissue } \\
\text { Tissue } \\
\text { Tissue } \\
\text { Plasma } \\
\text { Plasma } \\
\text { Plasma/Tissue } \\
\text { Plasma }\end{array}$ & $\begin{array}{l}\text { NGS,ddPCR } \\
\text { NGS } \\
\text { NGS } \\
\text { NGS } \\
\text { NGS } \\
\text { NGS } \\
\text { NGS }\end{array}$ & $\begin{array}{l}- \\
- \\
\text { MET Amp } \\
\text { P53 (1) } \\
\text { G796, L792 } \\
\text { L792(8), L718 (1), G796(1), PIK3CA (4) } \\
\text { EGFR Amp (29), MET Amp (10), BRAF } \\
\text { (3), PIK3CA (9) }\end{array}$ \\
\hline & Tan ASCO & Nazartinib & Tissue & NGS & MTOR del \\
\hline & Chabon & Rociletinib & Plasma & CAPP-Seq & - \\
\hline & Song & Olmutinib & Tissue & NGS & - \\
\hline C797G & Menon & Osimertinib & Tissue & NGS & EGFR and MYC Amp \\
\hline L792 & $\begin{array}{l}\text { Ou ASCO } \\
\text { Chen } \\
\text { lg Ou }\end{array}$ & Osimertinib & $\begin{array}{l}\text { Plasma/Tissue } \\
\text { Plasma } \\
\text { Plasma }\end{array}$ & $\begin{array}{l}\text { NGS } \\
\text { NGS } \\
\text { NGS }\end{array}$ & $\begin{array}{l}\text { C797S (8), PIK3CA (2) } \\
\text { C797S (3) } \\
\text { C797S, G796 }\end{array}$ \\
\hline L718 & $\begin{array}{l}\text { Ou ASCO } \\
\text { Bersanelli }\end{array}$ & Osimertinib & $\begin{array}{l}\text { Plasma/Tissue } \\
\text { Tissue }\end{array}$ & $\begin{array}{l}\text { NGS } \\
\text { NGS }\end{array}$ & $\begin{array}{l}\text { C797S (1), L792(2), G796(1), KRAS(1) } \\
-\end{array}$ \\
\hline G796 & $\begin{array}{l}\text { lg Ou } \\
\text { Ou ASCO }\end{array}$ & Osimertinib & $\begin{array}{l}\text { Plasma } \\
\text { Plasma/Tissue }\end{array}$ & $\begin{array}{l}\text { NGS } \\
\text { NGS }\end{array}$ & $\begin{array}{l}\text { L792, C797S } \\
\text { L792, C797S (1), L718(1) }\end{array}$ \\
\hline L798 & Chabon & Rociletinib & Plasma & CAPP-Seq & EGFR Amp \\
\hline E709K & Chabon & Rociletinib & Plasma & CAPP-Seq & - \\
\hline L692 V & Chabon & Rociletinib & Plasma & CAPP-Seq & - \\
\hline \multicolumn{6}{|c|}{ EGFR-independent mechanisms of resistance to third generation TKls } \\
\hline \multirow[t]{3}{*}{ Her 2 Amp } & $\begin{array}{l}\text { Planchard } \\
\text { Oxnard } \\
\text { Ramalingam }\end{array}$ & Osimertinib & $\begin{array}{l}\text { Tissue } \\
\text { Plasma/Tissue } \\
\text { Plasma }\end{array}$ & $\begin{array}{l}\mathrm{CGH} / \mathrm{FISH} \\
\mathrm{NGS} / \mathrm{CGH} \\
\mathrm{NGS}\end{array}$ & $\begin{array}{l}- \\
- \\
\text { P53, IDH2 }\end{array}$ \\
\hline & Ortiz-Cuaran & $\begin{array}{l}\text { Rociletinib/ } \\
\text { Osimertinib }\end{array}$ & Tissue & $\mathrm{FISH}$ & MET Amp(1) \\
\hline & Chabon & Rociletinib & Plasma & CAPP-Seq & $\begin{array}{l}\text { MET Amp(1), CDKN2A(1), EGFR Amp } \\
\text { and PIK3CA(1) }\end{array}$ \\
\hline \multirow[t]{3}{*}{ MET Amp } & $\begin{array}{l}\text { Planchard } \\
\text { Ou } \\
\text { Chia } \\
\text { Ramalingam } \\
\text { Ortiz-Cuaran } \\
\text { Piotrowska ASCO }\end{array}$ & Osimertinib & $\begin{array}{l}\text { Tissue } \\
\text { Tissue } \\
\text { Tissue } \\
\text { Plasma } \\
\text { Tissue } \\
\text { Plasma/Tissue }\end{array}$ & $\begin{array}{l}\text { NGS/CGH/IHC } \\
\text { ddPCR } \\
\text { NGS } \\
\text { FISH } \\
\text { FISH }\end{array}$ & $\begin{array}{l}- \\
- \\
- \\
\text { RB1 mut, P53 } \\
\text { Her2 Amp (1) } \\
-\end{array}$ \\
\hline & Tan ASCO & Nazartinib & Tissue & NGS & BRAF fusions \\
\hline & Chabon & Rociletinib & Plasma & CAPP-Seq & $\begin{array}{l}\text { CDKN2A(1), PIK3CA(1), PIK3CA, KRAS } \\
\text { and MET Amp(1),Her2 Amp(1) }\end{array}$ \\
\hline \multirow[t]{2}{*}{ KRAS mut } & $\begin{array}{l}\text { Ramalingam } \\
\text { Ortiz-Cuaran }\end{array}$ & Osimertinib & $\begin{array}{l}\text { Plasma } \\
\text { Tissue }\end{array}$ & $\begin{array}{l}\text { NGS } \\
\text { NGS }\end{array}$ & $\begin{array}{l}\text { CTNNB1 } \\
\text { C797S plasma }\end{array}$ \\
\hline & Chabon & Rociletinib & Plasma & CAPP-Seq & MET mut, MET amp, PIK3CA(1), KIT mut(1) \\
\hline NRAS mut & Eberlein & Osimertinib & Cell lines & NGS & - \\
\hline BRAF mut & $\begin{array}{l}\text { Oxnard } \\
\text { Ho et al. }\end{array}$ & Osimertinib & $\begin{array}{l}\text { Tissue } \\
\text { Cell lines }\end{array}$ & $\begin{array}{l}\text { NGS } \\
\text { MALDI }\end{array}$ & $\begin{array}{l}- \\
-\end{array}$ \\
\hline \multirow[t]{2}{*}{ PIK3CA mut } & $\begin{array}{l}\text { Oxnard } \\
\text { Ramalingam }\end{array}$ & Osimertinib & $\begin{array}{l}\text { Tissue } \\
\text { Plasma }\end{array}$ & $\begin{array}{l}\text { NGS } \\
\text { NGS }\end{array}$ & $\begin{array}{l}\text { P53, PTEN mut, NOTCH } \\
\text { P }\end{array}$ \\
\hline & Chabon & Rociletinib & Plasma & CAPP-Seq & $\begin{array}{l}\text { MET Amp (1), MET Amp, MET mut, } \\
\text { KRAS(1), EGFR and Her } 2 \text { Amp(1) }\end{array}$ \\
\hline PTEN loss & Kim & Osimertinib & Tissue & NGS & - \\
\hline $\begin{array}{l}\text { FGF2-FGFR1 } \\
\text { Autocrine loop }\end{array}$ & $\begin{array}{l}\text { Kim } \\
\text { Piotrowska ASCO }\end{array}$ & Osimertinib & $\begin{array}{l}\text { Tissue } \\
\text { Plasma/Tissue }\end{array}$ & $\begin{array}{l}\text { NGS } \\
\text { NGS }\end{array}$ & $\begin{array}{l}- \\
-\end{array}$ \\
\hline
\end{tabular}


Table 3 Mechanisms of resistance to third generation EGFR TKIs (Continued)

\begin{tabular}{|c|c|c|c|c|c|}
\hline Mechanism & Author & 3rd gen EGFR TKI & Sample & Method & Other mechanisms (no. of patients) \\
\hline \multirow[t]{2}{*}{$\mathrm{SCLC}$} & $\begin{array}{l}\text { Kim } \\
\mathrm{Ham} \\
\mathrm{Li}\end{array}$ & Osimertinib & $\begin{array}{l}\text { Tissue } \\
\text { Tissue } \\
\text { Tissue/Plasma }\end{array}$ & $\begin{array}{l}\text { NGS } \\
\text { NGS } \\
\text { NGS }\end{array}$ & $\begin{array}{l}\text { RB1 loss } \\
\text { EGFR Amp(1) } \\
\text { P53, PTEN, PIK3CA }\end{array}$ \\
\hline & Piotrowska & Rociletinib & Tissue/Plasma & NGS & RB1 loss(1), RB1 mut(1) \\
\hline
\end{tabular}

Amp amplification, BRAF B-Raf proto-oncogene, CAPP-Seq cancer personal profiling by deep sequencing, CDKN2A cyclin dependent kinase inhibitor $2 \mathrm{~A}$, CGH comparative genomic hybridization, CTNNB1 catenin beta 1 gene, ddPCR droplet digital polymerase chain reaction, EGFR Epidermal growth factor receptor, FGF2-FGFR1 FGF2-fibroblast growth factor receptor 1 (FGFR1), FISH fluorescent in situ hybridization, Her2 erb-b2 receptor tyrosine kinase 2, IDH2 isocitrate dehydrogenase 2, IHC immunohistochemistry, KIT KIT proto-oncogene receptor tyrosine kinase, KRAS KRAS proto-oncogene, MALDI matrix assisted laser desorption ionization-time of flight mass, MET MET protooncogene, MTOR mechanistic target of rapamysin kinase, mut mutation, MYC MYC proto-oncogene, NGS next generation sequencing, NOTCH NOTCH gene, NRAS NRAS proto-oncogene, PIK3CA phosphatidylinositol-4,5-bisphosphate 3-kinase catalytic subunit alpha, PTEN Phosphatase and tensin homolog, P53 tumour protein P53, RB1 RB transcriptional corepressor 1, SCLC small cell lung cancer, 3rd gen TKI third-generation tyrosine kinase inhibitor

64, 65, 68-70]. Interestingly, Her2 amplification and T790 M mutation appear to be mutually exclusive in patients who progressed on osimertinib $[49,64,68]$ but may co-exist in patients who progressed on rociletinib [52].

MET amplification has been described in both preclinical and clinical studies. Preclinical studies had shown MET amplification as a resistance mechanism to third generation TKI [71]. MET amplification had also been reported for patient who progressed on osimertinib $[69,70]$, rociletinib [52] and nazartinib. [53]

\section{PIK3CA mutations}

PIK3CA E545K mutation has been described as a resistant mechanism to osimertinib in at least two reports [49, 64]. Two PIK3CA gene mutations (E545K, E542K) were also described in 5 out of 43 patients who developed resistance to rociletinib [52].

\section{FGF2-fibroblast growth factor receptor (FGFR1)}

In vitro analysis demonstrated that FGF2 supplement conferred resistance to osimertinib in EGFR-mutant NSCLC cells [72]. Clinically FGFR amplification after progression on osimertinib were reported after osimertinib [72].

\section{Small cell transformation}

Small cell lung cancer (SCLC) transformation- a known rare mechanism of resistance to first generation TKI, has been described after treatment with third generation TKIs [54, 72-74]. These transformed SCLCs can continue to harbor their original EGFR-activating mutations, but not T790 M [54, 72-74]. Genome sequencing revealed $R B 1$ mutation and loss of $R B 1$ in these SCLC after acquired resistance to $3 r d$ generation TKI, suggesting that these mutations play critical roles in driving the transformation [54, 72]. Co-occurring P53, PTEN and PIK3CA mutations have also been reported in a patient with small cell transformation after osimertinib [74].

\section{Future directions}

a) Overcoming acquired resistance to third generation EGFR TKI

\section{Fourth generation EGFR TKIs}

The fourth generation EGFR TKIs are also under development. The current EGFR TKIs all target the ATPbinding site; however, the C797S mutation blocks the covalent binding of these drugs, conferring resistance. EAI001 and EAI045 were rationally identified as a molecule that binds allosterically to EGFR away from the binding site (non-ATP competitive), with specificity for mutant EGFR over wildtype EGFR [75]. EAI001 was found to have activity against L858R/T790 M mutant EGFR, but was less active against individual L858R or T790 M mutant EGFR. EAI045 was active in cell lines with individual L858R or T790 M mutations, or both [76]. In Ba/F3 cell lines bearing L858R/T790 M/C797S mutations, EAI045 was shown to result in control of cell proliferation when used in combination with cetuximab, but not when used as a single agent. This was attributed to the fact that if an EGFR dimer contained a wild-type and a mutant EGFR molecule, there would be differing susceptibilities to EAI045, compromising its activity. With the anti-EGFR monoclonal antibody cetuximab blocking EGFR dimerization, EAI045 can block these molecules in a monomer state [76]. Similar results were seen in mouse models carrying L8585R/T790 M/C797S $[76,77]$.

\section{Other novel EGFR inhibitors}

Gunther and colleagues recently developed a new class of trisubstituted pyridinyl imidazole EGFR inhibitors based on a p38 MAP kinase inhibitor compound [78, 79]. Using molecular modeling, authors synthesized 40 compounds with activity against EGFR mutants and systematically developed metabolically stable noncovalent reversible EGFR inhibitors. These compounds demonstrated efficacy against cells expressing the triple mutation (T790 M/C797S/L858R) with IC50 values of less than $10 \mathrm{nM}$ and also had more than 300 -fold selectivity for double EGFR mutant (T790 M/L858R) cells over wild-type EGFR. Further studies need to be done to evaluate the clinical efficacy and safety of these new compounds. 
First generation EGFR TKls after acquired resistance to third generation TKIs

Niederst et al. further described that cell lines harboring dual C797S and EGFR activating mutations (C797S/ del19) without the T790 M mutation were resistant to third-generation TKIs but retained sensitivity to gefitinib or afatinib [55]. In a patient who progressed on osimertinib and developed the dual EGFR mutation (C797S/ del19), treatment with gefinitib resulted in partial response and meaningful clinical improvement [80]. This suggests that patients treated with third generation TKIs in the first line setting who acquire resistance driven by C797S but remain undetectable for T790 M may subsequently respond to first-generation TKIs.

\section{First and third generation EGFR TKI combinations}

The configuration of T790 M and C797S mutations using cell line MGH121 Res \#1 has been found to be an important feature in predicting response to treatment. When the mutations occur in trans (i.e. on separate alleles), cells are resistant to third generation EGFR TKIs but sensitive to a combination of first and third generation EGFR TKIs. However, when the mutations occur in cis, no EGFR TKIs alone or in combination are effective. [55] In a patient who developed the triple mutation (T790 M/C797S/del19) in trans after progression on osimertinib, the combination of erlotinib and osimertinib was able to achieve partial response with undetectable C797S by ctDNA analysis after one month and further sustained response after two months of treatment. Strikingly, at disease progression after three months of therapy, C797S located in trans to T790 M remained undetectable but $\mathrm{C} 797 \mathrm{~S}$ in cis to T790 $\mathrm{M}$ appeared. The patient did not respond to further treatment with EGFR TKIs and subsequently required chemotherapy for disease control [81].

\section{Brigatinib and anti-EGFR antibodies}

Brigatinib (AP-26113) is a dual anaplastic lymphoma kinase (ALK) and EGFR inhibitor. Uchibori and colleagues screened the growth inhibitory activity of 30 existing tyrosine kinase inhibitors against $\mathrm{Ba} / \mathrm{F} 3$ cell lines overexpressing the triple mutation (T790 M/C797S/ del19). They subsequently identified brigatinib as the only compound to have significant albeit modest activity in vitro and in vivo. Docking and molecular dynamic simulations demonstrated that brigatinib was able to bind to the triple-mutant EGFR ATP-binding pocket. Of interest, when combined with an anti-EGFR antibody (either cetuximab or panitumumab), there was enhanced efficacy against triple-mutant $\mathrm{Ba} / \mathrm{F} 3$ cell lines, with a three-fold decrease in IC50 of brigatinib. This combination also successfully prolonged the survival of PC9 triple-mutant xenograft-bearing mice, at low toxicities.
Brigatinib in combination with anti-EGFR antibodies is a promising strategy to overcoming triple mutations [82].

\section{Third generation TKIs in combination with MEK inhibitors} In vitro studies using PC9 cell lines harboring the triple mutation (T790 M/C797S/del19) revealed that modulation of Bim and Mcl-1 levels was critical to mediating resistance against osimertinib induced apoptosis. Use of a MEK inhibitor to suppress ERK-dependent phosphorylation of Bim and Mcl-1 restored the ability of osimertinib to induce apoptosis in these cells. These findings suggest co-targeting MEK/ERK signaling is another possible strategy to overcoming triple mutations [83].

\section{In combination with oxidative phosphorylation inhibitors}

Use of osimertinib in combination with oxidative phosphorylation (OxPhos) inhibitors is another strategy currently being explored in the preclinical setting. Martin et al. demonstrated that EGFR mutant cell lines treated with osimertinib resulted in inhibition of glycolysis and consequent dependence on mitochondrial oxidative phosphorylation. Simultaneous treatment with OxPhos inhibitors (including phenformin, buformin, metformin, BAY 87-2243 and oligomycin) increased the sensitivity of EGFR mutant cells to osimertinib and was able to delay the development of osimertinib resistance in a dose dependent manner [84]. This represents a novel strategy that warrants further investigation.

\section{Osimertinib to treat EGF816 failure}

A final strategy in the management of resistance to third generation TKIs is the use of alternative third generation TKIs. Cross-resistance between various third generation TKIs has not yet been well studied. A recent abstract published at ASCO 2017 recruited patients with T790 M mutations who had progressed on EGF816 and were subsequently given osimertinib. Osimertinib had a response rate of $14 \%$, with a median treatment duration of 9 months, signifying meaningful clinical benefit [85]. This highlights the possibility of sequential third generation TKIs in the treatment of NSCLC.

\section{b) Sequencing of EGFR TKIs:}

Osimertinib has demonstrated better PFS and less toxicity compared to first generation EGFR TKI based on FLAURA results. Furthermore, it has been shown to be also effective for patients with CNS metastases. OS is immature at the present moment but unless it is detrimental, osimertinib will likely become the preferred EGFR TKI in the first line setting [21].

At present, there is no head-to-head comparison between osimertinib and second generation EGFR TKIs. Osimertinib in the first line setting demonstrated 


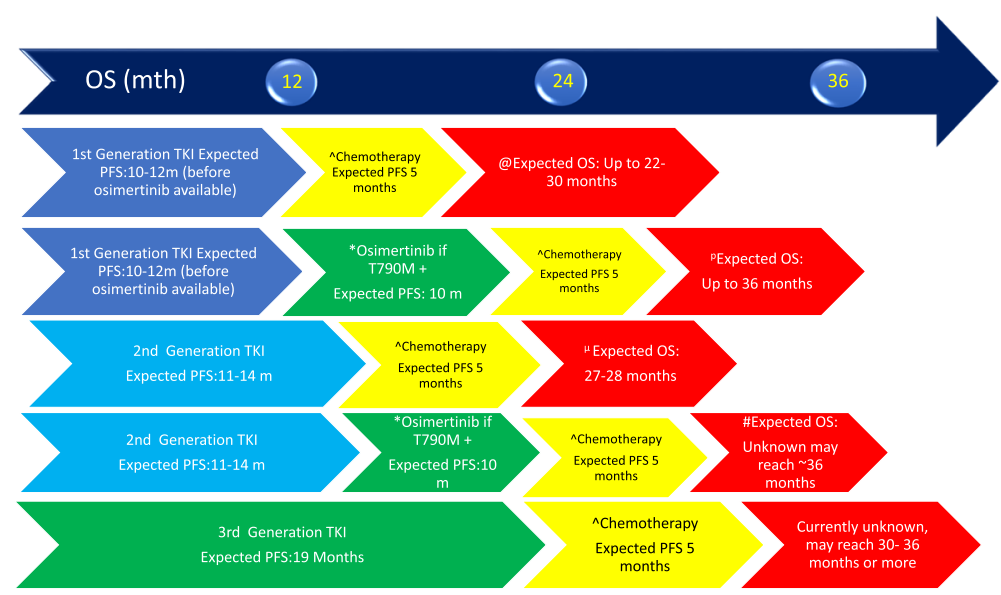

Fig. 2 Potential Sequencing of EGFR Tyrosine Kinase Inhibitors and its Estimated Overall Survival (OS). @ Estimated based on First Line EGFR TKI studies IPASS, WJTOG3405. *Estimated based on Pooled analysis AURA Extension \& AURA2 as well as AURA3 Study. P Estimated based on OS reported from the Pooled analysis AURA. Extension \& AURA2 Reported OS: 26.8 months + 10-12 months expected PFS from 1st Gen TKI. $\mu$ updated OS from Lux Lung 7. \#Currently limited data. Only 10\% of patients received osimertinib post progression on Afatinib in Lux Lung 7. OS for these $10 \%$ patients is not available. ^ Estimated based on AURA3

median PFS of around 19 months [21] as compared to second generation EGFR TKIs of around 11-14 months $[7,8]$. Furthermore, the toxicity profiles of osimertinib which is WT sparing is much more favourable compared to second generation EGFR TKI which has higher rate of skin and diarrhea toxicities. See Fig. 2 for illustration of overall survival estimation from various sequencing potential of EGFR TKIs.

Only about half of patients who were started upfront with first or second generation EGFR TKI will develop T790 $\mathrm{M}$ acquired mutation which will allow the subsequent treatment with osimertinib. The rest of the patients would unfortunately be treated with conventional chemotherapy.

The acquired resistance mechanisms with upfront treatment with osimertinib is not well understood. These patients at present do not have any clear options aside from cytotoxic chemotherapy or enrolment into a clinical trial. Early report from phase I AURA study, 3 out of 9 patients had both p53 and RB1 mutations which are known to be predictive of small cell transformation [64]. The dataset is very small at the present moment and should be interpreted with caution.

\footnotetext{
Abbreviations

ARMS: amplified refractory mutation system; $\mathrm{Cl}$ : confidence interval;

CNS: central nervous system; CTCs: circulating tumor cells; ctDNA: circulating tumor DNA; DCR: disease control rate; DHPLC: denaturing high performance liquid chromatography; EGFR: epidermal growth factor receptor; FGFR: fibroblast growth factor receptor; HR: hazard ratio; ILD: interstitial lung disease; MTD: maximum tolerated dose; NGS: next generation sequencing; nM: nanomolar; NSCLC: non-small cell lung cancer; ORR: objective response rate; PCR: polymerase chain reaction; PFS: progression free survival; PROs: patient reported outcomes; RP2D: recommended phase II dose; SoC: standard of care; TEN: toxic epidermal necrolysis; TKI: tyrosine kinase inhibitor; WT: wild-type
}

\section{Acknowledgements}

RAS is supported by the National Medical Research Council NMRC/CG/012/ 2013, the National Research Foundation Singapore, the Singapore Ministry of Education under its Research Centres of Excellence initiative.

\section{Funding}

Not applicable.

\section{Availability of data and materials Not applicable.}

\section{Authors' contributions}

CST and RAS contributed to the conception and outline of the review. All authors involved in drafting and revising the manuscript including giving the final approval of the version of the manuscript to be published.

\section{Ethics approval and consent to participate}

Not applicable.

\section{Consent for publication}

Not applicable.

\section{Competing interests}

Chee-Seng Tan has received honoraria from AstraZeneca, Merck, Boehringer Ingelheim, Novartis, Eli-Lilly, Eisai and Bristol-Myers Squibb; Ross Soo has received honoraria from Astra-Zeneca, BMS, Boehringer Ingelheim, Eli-Lilly, Merck, Novartis, Pfizer, Roche, Taiho and research grant from Astra-Zeneca. HYQ, NBK, YALE, JCRE declared no conflict of interests.

\section{Publisher's Note}

Springer Nature remains neutral with regard to jurisdictional claims in published maps and institutional affiliations.

\section{Author details}

'Department of Haematology-Oncology, National University Cancer Institute of Singapore, National University Health System, 1E Kent Ridge Road, NUHS Tower Block, Level 7, Singapore 119228, Singapore. ${ }^{2}$ Cancer Science Institute of Singapore, National University of Singapore, Singapore, Singapore.

${ }^{3}$ Department of Pharmacology, Yong Loo Lin School of Medicine, National University Health System, Singapore, Singapore. ${ }^{4}$ School of Surgery, The University of Western Australia, Perth, Australia. 


\section{Received: 1 November 2017 Accepted: 1 February 2018} Published online: 19 February 2018

\section{References}

1. Mok TS, Wu YL, Thongprasert S, Yang CH, Chu DT, Saijo N, Sunpaweravong P, Han B, Margono B, Ichinose Y, et al. Gefitinib or carboplatin-paclitaxel in pulmonary adenocarcinoma. N Engl J Med. 2009;361(10):947-57.

2. Maemondo M, Inoue A, Kobayashi $K$, Sugawara S, Oizumi S, Isobe $H$, Gemma A, Harada M, Yoshizawa H, Kinoshita I, et al. Gefitinib or chemotherapy for non-small-cell lung cancer with mutated EGFR. N Engl J Med. 2010;362(25):2380-8.

3. Mitsudomi T, Morita S, Yatabe Y, Negoro S, Okamoto I, Tsurutani J, Seto T, Satouchi M, Tada H, Hirashima T, et al. Gefitinib versus cisplatin plus docetaxel in patients with non-small-cell lung cancer harbouring mutations of the epidermal growth factor receptor (WJTOG3405): an open label, randomised phase 3 trial. The Lancet Oncol. 2010;11(2):121-8.

4. Zhou C, Wu YL, Chen G, Feng J, Liu XQ, Wang C, Zhang S, Wang J, Zhou S, Ren $\mathrm{S}$, et al. Erlotinib versus chemotherapy as first-line treatment for patients with advanced EGFR mutation-positive non-small-cell lung cancer (OPTIMAL, CTONG-0802): a multicentre, open-label, randomised, phase 3 study. The Lancet Oncol. 2011;12(8):735-42.

5. Rosell R, Carcereny E, Gervais R, Vergnenegre A, Massuti B, Felip E, Palmero R, Garcia-Gomez R, Pallares C, Sanchez JM, et al. Erlotinib versus standard chemotherapy as first-line treatment for European patients with advanced EGFR mutation-positive non-small-cell lung cancer (EURTAC): a multicentre, open-label, randomised phase 3 trial. The Lancet Oncol. 2012;13(3):239-46.

6. Gazdar AF. Activating and resistance mutations of EGFR in non-small-cell lung cancer: role in clinical response to EGFR tyrosine kinase inhibitors. Oncogene. 2009;28(Suppl 1):S24-31.

7. Park K, Tan EH, O'Byrne K, Zhang L, Boyer M, Mok T, Hirsh V, Yang JC, Lee $\mathrm{KH}$, Lu S, et al. Afatinib versus gefitinib as first-line treatment of patients with EGFR mutation-positive non-small-cell lung cancer (LUX-lung 7): a phase 2B, open-label, randomised controlled trial. The Lancet Oncol. 2016; 17(5):577-89.

8. Wu YL, Cheng Y, Zhou X, Lee KH, Nakagawa K, Niho S, Tsuji F, Linke R, Rosell R, Corral J, et al. Dacomitinib versus gefitinib as first-line treatment for patients with EGFR-mutation-positive non-small-cell lung cancer (ARCHER 1050): a randomised, open-label, phase 3 trial. The Lancet Oncol. 2017;

9. Tan CS, Gilligan D, Pacey S. Treatment approaches for EGFR-inhibitorresistant patients with non-small-cell lung cancer. The Lancet Oncol. 2015; 16(9):e447-e459.

10. Stewart EL, Tan SZ, Liu G, Tsao MS. Known and putative mechanisms of resistance to EGFR targeted therapies in NSCLC patients with EGFR mutations-a review. Translational lung cancer research. 2015;4(1):67-81.

11. Morgillo F, Della Corte CM, Fasano M, Ciardiello F. Mechanisms of resistance to EGFR-targeted drugs: lung cancer. ESMO open. 2016;1(3):e000060.

12. Yu HA, Arcila ME, Rekhtman N, Sima CS, Zakowski MF, Pao W, Kris MG, Miller VA, Ladanyi M, Riely GJ. Analysis of tumor specimens at the time of acquired resistance to EGFR-TKI therapy in 155 patients with EGFR-mutant lung cancers. Clinical cancer research: an official journal of the American Association for Cancer Research. 2013;19(8):2240-7.

13. Tan CS, Cho BC, Soo RA. Next-generation epidermal growth factor receptor tyrosine kinase inhibitors in epidermal growth factor receptor -mutant nonsmall cell lung cancer. Lung cancer (Amsterdam, Netherlands). 2016;93:59-68.

14. Wang S, Cang S, Liu D. Third-generation inhibitors targeting EGFR T790M mutation in advanced non-small cell lung cancer. J Hematol Oncol. 2016;9:34.

15. Cross DA, Ashton SE, Ghiorghiu S, Eberlein C, Nebhan CA, Spitzler PJ, Orme JP, Finlay MR, Ward RA, Mellor MJ, et al. AZD9291, an irreversible EGFR TKI, overcomes T790M-mediated resistance to EGFR inhibitors in lung cancer. Cancer discovery. 2014;4(9):1046-61.

16. Ballard P, Yates JW, Yang Z, Kim DW, Yang JC, Cantarini M, Pickup K, Jordan A, Hickey M, Grist M, et al. Preclinical comparison of Osimertinib with other EGFR-TKIs in EGFR-mutant NSCLC brain metastases models, and early evidence of clinical brain metastases activity. Clinical cancer research: an official journal of the American Association for Cancer Research. 2016;22(20): 5130-40.

17. Janne PA, Yang JC, Kim DW, Planchard D, Ohe Y, Ramalingam SS, Ahn MJ, Kim SW, Su WC, Horn L, et al. AZD9291 in EGFR inhibitor-resistant nonsmall-cell lung cancer. N Engl J Med. 2015;372(18):1689-99.

18. Goss G, Tsai CM, Shepherd FA, Bazhenova L, Lee JS, Chang GC, Crino L, Satouchi M, Chu Q, Hida T, et al. Osimertinib for pretreated EGFR
Thr790Met-positive advanced non-small-cell lung cancer (AURA2): a multicentre, open-label, single-arm, phase 2 study. The Lancet Oncol. 2016; 17(12):1643-52.

19. Goss G, Tsai C-M, Shepherd F, Ahn M-J, Bazhenova L, Crinò L, De Marinis F, Felip E, Morabito A, Hodge R, et al. MA16.11 CNS Response to Osimertinib in Patients with T790M-Positive Advanced NSCLC: Pooled Data from Two Phase II Trials. J of Thoracic Oncol. 12(1):S440-1.

20. Mok TS, Wu YL, Ahn MJ, Garassino MC, Kim HR, Ramalingam SS, Shepherd FA, He Y, Akamatsu H, Theelen WS, et al. Osimertinib or platinumPemetrexed in EGFR T790M-positive lung cancer. N Engl J Med. 2017;376(7): $629-40$.

21. Soria J-C, Ohe Y, Vansteenkiste J, Reungwetwattana T, Chewaskulyong B, Lee KH, Dechaphunkul A, Imamura F, Nogami N, Kurata T, et al. Osimertinib in untreated EGFR-mutated advanced non-small cell lung cancer. N Engl J Med. 2017, Nov 18; https://doi.org/10.1056/NEJMoa1713137 ePub ahead of print.

22. Park K, Lee J-S, Lee KH, Kim J-H, Cho BC, Min YJ, Cho JY, Han J-Y, Kim B-S, Kim J-S, et al. BI 1482694 (HM61713), an EGFR mutant-specific inhibitor, in T790M+ NSCLC: Efficacy and safety at the RP2D. J of Clin Oncol. 2016; 34(15_suppl):9055-5.

23. Boehringer Ingelheim returns development and commercial rights of olmutinib to Hanmi Pharmaceutical [https:/www.boehringer-ingelheim. com/press-release/boehringer-ingelheim-returns-development-commercialrights-olmutinib-hanmi].

24. Ministry of Food and Drug Safety (South Korea). Safety report on olmutinib (article in Korean) [http://www.mfds.go.kr/index.do?mid=676\&pageNo= $1 \&$ seq $=33700 \& \mathrm{cmd}=\mathrm{v}]$.

25. Lelais G, Epple R, Marsilje TH, Long YO, McNeill M, Chen B, Lu W, Anumolu J, Badiger S, Bursulaya B, et al. Discovery of (R,E)-N-(7-Chloro-1-(1-[4(dimethylamino)but-2-enoyl]azepan-3-yl)-1H-benzo[d]imidazol-2-yl)-2methylisonicotinamide (EGF816), a novel, potent, and WT sparing covalent inhibitor of oncogenic (L858R, ex19del) and resistant (T790M) EGFR mutants for the treatment of EGFR mutant non-small-cell lung cancers. J Med Chem. 2016:59(14):6671-89.

26. Tan DSW, Yang JCH, Leighl NB: Updated results of a phase 1 study of EGF816, a third-generation, mutant-selective EGFR tyrosine kinase inhibitor (TKI), in advanced non-small cell lung cancer (NSCLC) harboring T790M. Journal of clinical oncology: official journal of the American Society of Clinical Oncology 2016(3415(Suppl):abstr9044).

27. Planken S, Behenna DC, Nair SK, Johnson TO, Nagata A, Almaden C, Bailey S, Ballard TE, Bernier L, Cheng H, et al. Discovery of N-((3R,4R)-4-Fluoro-1-(6-((3methoxy-1-methyl-1 H-pyrazol-4-yl)amino)-9-methyl-9H- purin-2-yl)pyrrolidine3-yl) acrylamide (PF-06747775) through structure-based drug design: a high affinity irreversible inhibitor targeting oncogenic EGFR mutants with selectivity over wild-type EGFR. J Med Chem. 2017;60(7):3002-19.

28. Husain H, Martins R, Goldberg S, Senico P, Ma W, Masters J, Pathan N, Kim D-W, Socinski M, Goldberg Z, et al. P3.02b-001 phase 1 dose escalation of PF-06747775 (EGFR-T790M inhibitor) in patients with advanced EGFRm (del 19 or L858R+/-T790M) NSCLC. J Thorac Oncol. 12(1):S1185.

29. Xu X, Mao L, Xu W, Tang W, Zhang X, Xi B, Xu R, Fang X, Liu J, Fang C, et al. AC0010, an irreversible EGFR inhibitor selectively targeting mutated EGFR and overcoming T790M-induced resistance in animal models and lung cancer patients. Mol Cancer Ther. 2016;15(11):2586-97.

30. Long Wu Y, Zhou Q, Liu X, Zhang L, Zhou J, Wu L, An T, Cheng Y, Zheng X, Hu B et al: MA16.06 Phase 1/II Study of AC0010, Mutant-Selective EGFR Inhibitor, in Non-Small Cell Lung Cancer (NSCLC) Patients with EGFR T790M Mutation, vol. 12; 2017.

31. Wang $H$, Zhang L, Zheng $X$, Zhang $X$, Si X, Wang $M$. The ability of avitinib to penetrate the blood brain barrier and its control of intra-/extra-cranial disease in patients of non-small cell lung cancer (NSCLC) harboring EGFR T790M mutation. J of Clin Oncol. 2017;35(15_suppl):e20613-3.

32. Hong MH, Lee IY, Koh JS, Lee J, Suh B-C, Song H-J, Salgaonkar P, Lee J, Lee Y-S, Oh S-W, et al. P3.02b-119 YH25448, a Highly Selective 3rd Generation EGFR TKI, Exhibits Superior Survival over Osimertinib in Animal Model with Brain Metastases from NSCLC. J of Thoracic Oncol. 12(1):S1265-6.

33. Clovis Oncology announces regulatory update for rociletinib NDA filing. Business Wire [http://www.businesswire.com/news/home/20151116005513/en/].

34. Sequist LV, Soria JC, Camidge DR. Update to Rociletinib data with the RECIST confirmed response rate. N Engl J Med. 2016;374(23):2296-7.

35. Goto Y, Nokihara H, Murakami H, Shimizu T, Seto T, Krivoshik AP, Keating AT, Uegaki K, Takeda K, Komatsu K, et al. ASP8273, a mutant-selective 
irreversible EGFR inhibitor in patients (pts) with NSCLC harboring EGFR activating mutations: Preliminary results of first-in-human phase I study in Japan. J of Clin Oncol. 2015;33(15_suppl):8014-4.

36. Yu HA, Spira Al, Horn L, Weiss J, West HJ, Giaccone G, Evans TL, Kelly RJ, Desai BB, Krivoshik A, et al. Antitumor activity of ASP8273 300 mg in subjects with EGFR mutation-positive non-small cell lung cancer: Interim results from an ongoing phase 1 study. 2016; of Clinical Oncol, 34(15_ suppl):9050-0.

37. Astellas Announces Decision to Discontinue ASP8273 Treatment Arm and Close Randomization for Clinical Study Protocol 8273-CL-0302 [http:// newsroom.astellas.us/2017-05-10-Astellas-Announces-Decision-toDiscontinue-ASP8273-Treatment-and-Close-Randomization-for-ClinicalStudy-Protocol-8273-CL-0302].

38. (Royal College of Physicians). National Lung Cancer Audit annual report 2016 (for the audit period 2015) [https://www.rcplondon.ac.uk/projects/ outputs/nlca-annual-report-2016].

39. Wang Z, Chen R, Wang S, Zhong J, Wu M, Zhao J, Duan J, Zhuo M, An T, Wang $Y$, et al. Quantification and dynamic monitoring of EGFR T790M in plasma cell-free DNA by digital PCR for prognosis of EGFR-TKI treatment in advanced NSCLC. PLoS One. 2014;9(11):e110780.

40. Zheng D, Ye X, Zhang MZ, Sun Y, Wang JY, Ni J, Zhang HP, Zhang L, Luo J, Zhang J, et al. Plasma EGFR T790M ctDNA status is associated with clinical outcome in advanced NSCLC patients with acquired EGFR-TKI resistance. Sci Rep. 2016;6:20913.

41. Hosokawa M, Hayata T, Fukuda Y, Arakaki A, Yoshino T, Tanaka T, Matsunaga T. Size-selective microcavity Array for rapid and efficient detection of circulating tumor cells. Anal Chem. 2010;82(15):6629-35.

42. Sundaresan TK, Sequist LV, Heymach JV, Riely GJ, Janne PA, Koch WH, Sullivan JP, Fox DB, Maher R, Muzikansky A, et al. Detection of T790M, the acquired resistance EGFR mutation, by tumor biopsy versus noninvasive blood-based analyses. Clinical cancer research: an official journal of the American Association for Cancer Research. 2016;22(5):1103-10.

43. Pailler E, Adam J, Barthelemy A, Oulhen M, Auger N, Valent A, Borget I, Planchard D, Taylor M, Andre F, et al. Detection of circulating tumor cells harboring a unique ALK rearrangement in ALK-positive non-small-cell lung cancer. J Clin Oncol Off J Am Soc Clin Oncol. 2013;31(18):2273-81.

44. Huang WL, Chen YL, Yang SC, Ho CL, Wei F, Wong DT, Su WC, Lin CC. Liquid biopsy genotyping in lung cancer: ready for clinical utility? Oncotarget. 2017;8(11):18590-608.

45. Diaz LA, Bardelli A. Liquid biopsies: genotyping circulating tumor DNA. J Clin Oncol. 2014;32(6):579-86.

46. Thress KS, Brant R, Carr TH, Dearden S, Jenkins S, Brown H, Hammett $T$, Cantarini M, Barrett JC. EGFR mutation detection in ctDNA from NSCLC patient plasma: a cross-platform comparison of leading technologies to support the clinical development of AZD9291. Lung cancer (Amsterdam, Netherlands). 2015;90(3):509-15.

47. Karlovich C, Goldman JW, Sun JM, Mann E, Sequist LV, Konopa K, Wen W, Angenendt P, Horn L, Spigel D, et al. Assessment of EGFR mutation status in matched plasma and tumor tissue of NSCLC patients from a phase I study of Rociletinib (CO-1686). Clinical cancer research: an official journal of the American Association for Cancer Research. 2016:22(10):2386-95.

48. Ercan D, Choi HG, Yun CH, Capelletti M, Xie T, Eck MJ, Gray NS, Janne PA. EGFR mutations and resistance to irreversible pyrimidine-based EGFR inhibitors. Clinical cancer research: an official journal of the American Association for Cancer Research. 2015;21(17):3913-23.

49. Oxnard GR, Thress K, Paweletz C, Stetson D, Dougherty B, Markovets A, Janne PA: ORAL17.07 Mechanisms of Acquired Resistance to AZD9291 in EGFR T790M Positive Lung Cancer. J of Thoracic Oncol 2015(10(9 Suppl.2); ORAL 17.07).

50. Thress KS, Paweletz CP, Felip E, Cho BC, Stetson D, Dougherty B, Lai Z, Markovets A, Vivancos A, Kuang Y, et al. Acquired EGFR C797S mutation mediates resistance to AZD9291 in non-small cell lung cancer harboring EGFR T790M. Nat Med. 2015;21(6):560-2.

51. Song HN, Jung KS, Yoo KH, Cho J, Lee JY, Lim SH, Kim HS, Sun JM, Lee SH, Ahn JS, et al. Acquired C797S mutation upon treatment with a T790Mspecific third-generation EGFR inhibitor (HM61713) in non-small cell lung cancer. Journal of thoracic oncology: official publication of the International Association for the Study of Lung Cancer. 2016;1 1(4):e45-7.

52. Chabon JJ, Simmons AD, Lovejoy AF, Esfahani MS, Newman AM, Haringsma HJ, Kurtz DM, Stehr H, Scherer F, Karlovich CA, et al. Circulating tumour DNA profiling reveals heterogeneity of EGFR inhibitor resistance mechanisms in lung cancer patients. Nat Commun. 2016;7:11815.
53. Tan DS-W, Kim D-W, Leighl NB, Riely GJ, Yang JC-H, Wolf J, Seto T, Felip E, Aix SP, Jonnaert M, et al. Genomic profiling of resistant tumor samples following progression on EGF816, a third generation, mutant-selective EGFR tyrosine kinase inhibitor (TKI), in advanced non-small cell lung cancer (NSCLC). J of Clin Oncol. 2017;35(15_suppl):11506-6.

54. Piotrowska Z, Niederst MJ, Karlovich CA, Wakelee HA, Neal JW, MinoKenudson M, Fulton L, Hata AN, Lockerman EL, Kalsy A, et al. Heterogeneity underlies the emergence of EGFRT790 wild-type clones following treatment of T790M-positive cancers with a third-generation EGFR inhibitor. Cancer discovery. 2015;5(7):713-22.

55. Niederst MJ, Hu H, Mulvey HE, Lockerman EL, Garcia AR, Piotrowska Z, Sequist LV, Engelman JA. The allelic context of the C797S mutation acquired upon treatment with third-generation EGFR inhibitors impacts sensitivity to subsequent treatment strategies. Clinical cancer research: an official journal of the American Association for Cancer Research. 2015;21(17): 3924-33.

56. Piotrowska Z, RJ N, Fairclough S, Lanman RB, Marcoux N, Gettinger SN, Owonikoko TK, Ramalingam SS, V. SL: OA 09.01- characterizing the genomic landscape of EGFR C797S in lung cancer using ctDNA next-generation sequencing. IASLC World Conference on Lung Cancer 2017.

57. Menon R, Muller J, Schneider P, Lakis S, Thress K, Wolf J, Heukamp L, Heuckmann JM, Griesinger F, Novel A. EGFR (C797) variant detected in a pleural biopsy specimen from an Osimertinib-treated patient using a comprehensive hybrid capture-based next-generation sequencing assay. Journal of thoracic oncology: official publication of the International Association for the Study of Lung Cancer. 2016;11(9):e105-7.

58. Ou Q, Wu X, Bao H, Tong X, Wang X, Zhang X, Chang Z, Mao Y, Shao Y, Zhou $C$. Investigating novel resistance mechanisms to third generation EGFR TKI osimertinib in non-small cell lung cancer patients using next generation sequencing. J Clin Oncol. 2017:35(15_suppl):2572-2.

59. Ou SI, Cui J, Schrock AB, Goldberg ME, Zhu WW, Albacker L, Stephens PJ, Miller VA, Ali SM. Emergence of novel and dominant acquired EGFR solventfront mutations at Gly796 (G796S/R) together with C797S/R and L792F/H mutations in one EGFR (L858R/T790M) NSCLC patient who progressed on osimertinib. Lung cancer (Amsterdam, Netherlands). 2017;108:228-31.

60. Chen K, Zhou F, Shen W, Jiang T, Wu X, Tong X, Shao YW, Qin S, Zhou C. Novel Mutations on EGFR Leu792 Potentially Correlate to Acquired Resistance to Osimertinib in Advanced NSCLC. J of Thoracic Oncol. 12(6):e65-8.

61. Bersanelli M, Minari R, Bordi P, Gnetti L, Bozzetti C, Squadrilli A, Lagrasta CA, Bottarelli L, Osipova G, Capelletto E, et al. L718Q mutation as new mechanism of acquired resistance to AZD9291 in EGFR-mutated NSCLC. Journal of thoracic oncology: official publication of the International Association for the Study of Lung Cancer. 2016;11(10):e121-3.

62. Yam I, Lam DC, Chan K, Chung-Man Ho J, Ip M, Lam WK, Chan TK, Chan V. EGFR array: uses in the detection of plasma EGFR mutations in non-small cell lung cancer patients. Journal of thoracic oncology: official publication of the International Association for the Study of Lung Cancer. 2012;7(7):1131-40.

63. Cheng C, Wang R, Li Y, Pan Y, Zhang Y, Li H, Zheng D, Zheng S, Shen X, Sun $Y$, et al. EGFR exon 18 mutations in east Asian patients with lung adenocarcinomas: a comprehensive investigation of prevalence, Clinicopathologic characteristics and prognosis. Sci Rep. 2015;5:13959.

64. Ramalingam SS, Yang JCH, Lee CK, Kurata T, Kim D-W, John T, Nogami N, Ohe Y, Mann H, Rukazenkov Y, et al. Osimertinib As First-Line Treatment of EGFR Mutation-Positive Advanced Non-Small-Cell Lung Cancer. J of Clin Oncol. 2017; JCO.2017.2074.7576

65. Ortiz-Cuaran S, Scheffler M, Plenker D, Dahmen L, Scheel AH, FernandezCuesta L, Meder L, Lovly CM, Persigehl T, Merkelbach-Bruse S, et al. Heterogeneous mechanisms of primary and acquired resistance to thirdgeneration EGFR inhibitors. Clinical cancer research: an official journal of the American Association for Cancer Research. 2016;22(19):4837-47.

66. Eberlein CA, Stetson D, Markovets AA, Al-Kadhimi KJ, Lai Z, Fisher PR, Meador CB, Spitzler P, Ichihara E, Ross SJ, et al. Acquired resistance to the mutant-selective EGFR inhibitor AZD9291 is associated with increased dependence on RAS signaling in preclinical models. Cancer Res. 2015;75(12): 2489-500.

67. Ho CC, Liao WY, Lin CA, Shih JY, Yu CJ, Chih-Hsin Yang J. Acquired BRAF V600E mutation as resistant mechanism after treatment with Osimertinib. Journal of thoracic oncology: official publication of the International Association for the Study of Lung Cancer. 2017;12(3):567-72.

68. Planchard D, Loriot Y, Andre F, Gobert A, Auger N, Lacroix L, Soria JC. EGFRindependent mechanisms of acquired resistance to AZD9291 in EGFR 
T790M-positive NSCLC patients. Annals of oncology: official journal of the European Society for Med Oncol. 2015;26(10):2073-8.

69. Ou SI, Agarwal N, Ali SM. High MET amplification level as a resistance mechanism to osimertinib (AZD9291) in a patient that symptomatically responded to crizotinib treatment post-osimertinib progression. Lung cancer (Amsterdam, Netherlands). 2016;98:59-61.

70. Piotrowska Z, Thress KS, Mooradian M, Heist RS, Azzoli CG, Temel JS, Rizzo C, Nagy RJ, Lanman RB, Gettinger SN, et al. MET amplification (amp) as a resistance mechanism to osimertinib. J of Clin Oncol. 2017;35(15_suppl): 9020-0.

71. Shi P, Oh YT, Zhang G, Yao W, Yue P, Li Y, Kanteti R, Riehm J, Salgia R, Owonikoko TK, et al. Met gene amplification and protein hyperactivation is a mechanism of resistance to both first and third generation EGFR inhibitors in lung cancer treatment. Cancer Lett. 2016;380(2):494-504.

72. Kim TM, Song A, Kim DW, Kim S, Ahn YO, Keam B, Jeon YK, Lee SH, Chung DH, Heo DS. Mechanisms of acquired resistance to AZD9291: a mutationselective, irreversible EGFR inhibitor. Journal of thoracic oncology: official publication of the International Association for the Study of Lung Cancer. 2015;10(12):1736-44.

73. Ham JS, Kim S, Kim HK, Byeon S, Sun JM, Lee SH, Ahn JS, Park K, Choi YL, Han J, et al. Two cases of small cell lung cancer transformation from EGFR mutant adenocarcinoma during AZD9291 treatment. Journal of thoracic oncology: official publication of the International Association for the Study of Lung Cancer. 2016;11(1):e1-4.

74. Li L, Wang H, Li C, Wang Z, Zhang P, Yan X. Transformation to small-cell carcinoma as an acquired resistance mechanism to AZD9291: a case report. Oncotarget. 2017;8(11):18609-14.

75. Wang S, Song Y, Liu D. EAI045: the fourth-generation EGFR inhibitor overcoming T790M and C797S resistance. Cancer Lett. 2017;385:51-4.

76. Jia Y, Yun CH, Park E, Ercan D, Manuia M, Juarez J, Xu C, Rhee K, Chen T, Zhang H, et al. Overcoming EGFR(T790M) and EGFR(C797S) resistance with mutant-selective allosteric inhibitors. Nature. 2016;534(7605):129-32.

77. Li D, Shimamura T, Ji H, Chen L, Haringsma HJ, McNamara K, Liang MC, Perera SA, Zaghlul S, Borgman CL, et al. Bronchial and peripheral murine lung carcinomas induced by T790M-L858R mutant EGFR respond to HKI-272 and rapamycin combination therapy. Cancer Cell. 2007;12(1):81-93.

78. Gunther M, Juchum M, Kelter G, Fiebig H, Laufer S. Lung cancer: EGFR inhibitors with low Nanomolar activity against a therapy-resistant L858R T790M/C797S mutant. Angewandte Chemie (International ed in English). 2016;55(36):10890-4.

79. Gunther M, Lategahn J, Juchum M, Doring E, Keul M, Engel J, Tumbrink HL, Rauh D, Laufer S. Trisubstituted Pyridinylimidazoles as potent inhibitors of the clinically resistant L858R/T790M/C797S EGFR mutant: targeting of both hydrophobic regions and the phosphate binding site. J Med Chem. 2017; 60(13):5613-37.

80. Chic N, Mayo-de-las-Casas C, Reguart N. Successful Treatment with Gefitinib in Advanced Non-Small Cell Lung Cancer after Acquired Resistance to Osimertinib. J Thoracic Oncol. 12(6):e78-80.

81. Wang Z, Yang JJ, Huang J, Ye JY, Zhang XC, Tu HY, Han-Zhang H, Wu YL. Lung adenocarcinoma harboring EGFR T790M and in trans C797S responds to combination therapy of first- and third-generation EGFR TKIs and shifts allelic configuration at resistance. J Thorac Oncol. 2017;12(11):1723-7.

82. Uchibori K, Inase N, Araki M, Kamada M, Sato S, Okuno Y, Fujita N, Katayama R: Brigatinib combined with anti-EGFR antibody overcomes osimertinib resistance in EGFR-mutated non-small-cell lung cancer. 2017, 8:14768.

83. Shi P, Oh YT, Deng L, Zhang G, Qian G, Zhang S, Ren H, Wu G, Legendre B $\mathrm{Jr}$, Anderson E, et al. Overcoming acquired resistance to AZD9291, a thirdgeneration EGFR inhibitor, through modulation of MEK/ERK-dependent Bim and Mcl-1 degradation. Clinical cancer research: an official journal of the American Association for Cancer Research. 2017;

84. Martin MJ, Eberlein C, Taylor M, Ashton S, Robinson D, Cross D. Inhibition of oxidative phosphorylation suppresses the development of osimertinib resistance in a preclinical model of EGFR-driven lung adenocarcinoma. Oncotarget. 2016;7(52):86313-25.

85. Arbour KC, Sequist LV, Piotrowska Z, Kris MG, Paik PK, Ni A, Plodkowski A, Riely GJ, Yu HA. Response to osimertinib following treatment with EGF816 in patients with T790M EGFR mutant NSLCLC. J Clin Oncol. 2017;35(15_ suppl):e20673-3.

\section{Submit your next manuscript to BioMed Central and we will help you at every step:}

- We accept pre-submission inquiries

- Our selector tool helps you to find the most relevant journal

- We provide round the clock customer support

- Convenient online submission

- Thorough peer review

- Inclusion in PubMed and all major indexing services

- Maximum visibility for your research

Submit your manuscript at www.biomedcentral.com/submit
(O) BioMed Central 